\title{
The Buddhist Temple in the Imperial City of Saint Petersburg. A Different Way of Cultural Integration
}

\author{
Oyungerel Tangad \\ Institute of Archaeology and Ethnology, \\ Polish Academy of Sciences, Warsaw
}

\begin{abstract}
This article intends to examine the founding and functioning of the Buddhist temple in Saint Petersburg at the turn of the $20^{\text {th }}$ century presented within the context of a cosmopolitan urban landscape. Moreover, it demonstrates the forms and aims of the sociopolitical activity of scholars originating from the Rozen School, which contributed to the emergence of the temple. As an example of specifically Russian orientalism, this scholarly activity enabled thinking in the categories of ethnic pluralism and principles of multiculturalism in the national policy of the Russian Empire in the discussed period, thus constituting one of the key elements which enabled the foundation of the temple.
\end{abstract}

Keywords: Buddhist temple, datsan Gunzechoinei, imperialism, Rozen School, Russian orientalism, Saint Petersburg, urban landscape

\section{INTRODUCTION}

The present article was inspired by reflecting on the Buddhist Gunzenchoinei temple erected in Saint Petersburg ${ }^{1}$ at the beginning of the $20^{\text {th }}$ century. ${ }^{2}$ The temple belongs to the Gelugpa tradition (also referred to as the school of 'Yellow Hats' - the youngest school of Tibetan Buddhism, established in the $15^{\text {th }}$ century and popular among Tibetan and Mongolian people). The Gelugpa tradition is characterized by a highly developed ceremonial component wherein the complexities of ritual practices are deeply rooted

1 The original name of the city of Saint Petersburg (Russian: Sankt Petersburg) underwent numerous changes: Petrograd (1914-1924), Leningrad (1924-1991), and since 1991 Saint Petersburg once more. For functional reasons one name (Saint Petersburg) is used for all periods in this article.

2 Research for this project was funded by the National Science Center Grant No. UMO-2015/19/B/ HS3/02143, under the project entitled Inscenizowana inność. Ludzkie odmienności w Europie Środkowej, 1850-1939 (Staged Otherness. Human Oddities in Central and Eastern Europe, 18501939). I would like to express my gratitude to Dr Dominika Czarnecka, Professor Dagnosław Demski and Professor Kamila Baraniecka-Olszewska for their comments and suggestions which helped me clarify my own ideas and arguments. 
in the reality of Tibetan culture (NAMKHAI 2001). The emergence of such a temple (Mongolian: datsan) on the European continent at the beginning of the $20^{\text {th }}$ century, in the capital of Orthodox Russia, appears rather unusual and worth noticing.

The temple in Saint Petersburg was erected between 1909 and 1915, survived the dramatic events related to the $20^{\text {th }}$ century history of Russia and the Soviet Union and can currently be considered as one of the most interesting locations on the city map (AleKSEEv-APRAKSIN 2008; ANDREEv 1992; 2012a; 2012b). Its original shape, reflecting architectural syncretism, reveals the characteristics of both Tibetan temples and that of European buildings. In terms of the sociocultural dimension, the Gunzechoinei temple is a dynamically developing Buddhist center which attracts Buddhists of different nationalities (including an increasing number of ethnic Russians). The incentive of their visits range from praying and healing to learning as the temple hosts, among others, lectures in Buddhist philosophy.

The reasons underlying the emergence of the Saint Petersburg temple are most commonly explained by geopolitical conditions related to colonial conquests, i.e. Russia's struggle for influence in Central Asia (including Tibet). However, other factors contributing to this process should, in my opinion, also be mentioned. Among these, Russia's geopolitical position is of note, which raised questions concerning identity ambivalence arising from the country's location between Europe and Asia. Its consequence was visible through the peculiar characteristics of Russian orientalism, exemplified by the socio-political activity of the community of orientalists from the so-called Rozen School at the University of Saint Petersburg (ToLz 2005; 2013). The representatives of this school supported the ideas of linguistic and cultural pluralism concerning inorodcy ('those of different origins') - the Asian peoples inhabiting the eastern and southern peripheries of the Russian Empire. Scholars from the Rozen school believed that the ideas they represented were "fully compatible with pan-Russian nationalism" (Tolz 2005:127). This 'compatibility' of ideas found fertile ground for development within the territory of the thriving cosmopolitan Russian city of Saint Petersburg at the turn of the $20^{\text {th }}$ century.

The present article intends to demonstrate how and why the visions of Russian orientalist scholars could come true precisely in the city of Saint Petersburg. In this context, the 'exotic' Buddhist temple can be viewed as a material manifestation of these views in the urban landscape. Different forms of contact between urban audiences and the "Others" - the 'exotic' ones, existed in the capital of the Russian Empire at the time, such as ethnographic shows, circuses, variété, etc. The example of a Buddhist temple discussed in the present article also constitutes a form of intercultural contact. Even though the forms of contact with "Others" differed from one another significantly, they continued to function simultaneously. Ultimately, I intend to demonstrate interactions between urban audiences and "exotic Others" from a perspective divergent from what was typical of the ethnographic shows popular during that time period.

\section{THE IMPERIAL CITY OF SAINT PETERSBURG}

Much has already been written about the capital of the former Russian Empire. Saint Petersburg, referred to as "the city from nowhere, city without history, established on Finnish mud, built by strangers" (KeLLER 2001:7), demonstrated a character different 
than that of other Russian cities. Founded by Tsar Peter I in 1703, it became a "cultural phenomenon in the Russian history"; as an antithesis of Moscow - "the icon of old Ruthenia" (GARCZYK 2015:7). The city, founded on Enlightenment ideas, not only counted as the most 'European' of all Russian cities, but also the most 'foreign' within the boundaries of the Empire (KeLler 2001:7). In the Tsar's vision, Saint Petersburg was supposed to emerge as a modern, cosmopolitan city epitomizing the highest achievements of Europe at the time, simultaneously confirming the birth of the Russian Empire, due to which, among others, it became the capital city in 1712. Its construction process attracted the best architects and sculptors from Italy, France or Germany (GARCZYK 2015:23-24) as well as thousands of construction workers from all Russian gubernias and annexed territories such as the Kazan and Astrakhan or the Siberian and Crimean Khanates (GARCZYK 2015:104). The successors of the construction workers who did not return to their homelands settled down in Saint Petersburg and established their own city districts as well as a multicultural diaspora. ${ }^{3}$ The successors of Peter I continually moved in the 'European direction'. In the $18^{\text {th }}$ century, a Petersburg community of intelligentsia was formed of artists, painters and writers from Russia and abroad (ZAPESOTSKII - MICHAILOV 2011). Temples, theatres and museums were erected in this multiethnic and multireligious city, including, among others, the Hermitage (1754-1762), the Isaakievskii Sobor (1818-1858), the Mariinskii theatre (1783) as well as the Russkii Muzei museum complex (1895). In 1714, the first Russian museum of Kunstkamera was established using the private collections of Peter I and modelled on European curiosity cabinets. The collection of Peter I included books, manuscripts, rare objects and curiosities, primarily exhibits demonstrating human anatomical anomalies. In 1724, by the order of Tsar Peter I, the collections of Kunstkamera and the library established next to it were used to found the first institutions of the Russian Academy of Sciences in Saint Petersburg. The same year of 1724 is marked as the date of establishment of the University of Saint Petersburg (Sankt Peterburgskii Imperatorskii Universitet), though the date of 1819 can also be found in some archives for the same event.

As time went by, an intensive inflow of ideas and cultural novelties from Europe to the city could be observed, with the emerging scientific, educational and entertainment institutions visibly influenced by this process. In specific, "new theatres for laborers, bourgeoisie and small entrepreneurs were endlessly being opened here. The municipal authorities founded the theatre in the National House of Emperor Nicholas II. Since 1897 a theatre open to general public functioned at Novoadmiralteiskaia Street, in Saint Petersburg sea port, while in 1891 the theatre of Nevski Society of Popular Entertainment (Obshchestvo Narodnykh Rozvlechenii). In 1898 summer stages appeared in Ekateringovski and Petrovski parks along with the Summer Theatre in the Tavricheskii Garden. Premieres took place every day" (LikHACHEv 2011:6). During the same period circuses, panopticon museums, zoological gardens and amusement parks were founded in Saint Petersburg.

\footnotetext{
3 "Since the moment of city establishment the number of Russian inhabitants remained stable and numbered between $82 \%$ and $86 \%$ of the total number of inhabitants. The percentage of non-Russian inhabitants varied throughout the years, ranging between $6 \%$ and $18 \%$, reaching a peak of $25 \%$ during the World War I period." (GARCZYK 2015:9).
} 
Following the practice of public shows of peoples originating from territories outside Europe, which was developing in the second half of the $19^{\text {th }}$ century as well as the first decades of the $20^{\text {th }}$ century (see e.g. CZARnECKa 2018; DEMSKi 2018a; 2018b; NoviKova 2013), the Russian capital started hosting visits of "exotic Others" from distant lands. For a few decades, ethnographic shows in Russia functioned alongside traditional folk festivals (peterburgskie traditsionnye guliania) ${ }^{4}$ together they contributed to the urban entertainment landscape. On the one hand, "traditions originating from folk festivals and carnivals were used there, on the other, symbols and allegory of the school theatre" (NeKRYLOVA 1988:8).

Ultimately, however, Saint Petersburg was not a typical Western European city, but rather a combination of European elements with those that were traditionally considered to be Russian.

\section{SAINT PETERSBURG AND RUSSIAN ORIENTALISM}

The city of Saint Petersburg already attracted scholars and researchers from different corners of the Russian Empire, as well as Europe in the $18^{\text {th }}$ century. The development of science, including that of scientific institutions, was supported by Tsar Peter I as it corresponded with his vision of modernity, which involved scientific and technical progress as key components. Moreover, "in order to ensure high European level [of science - O.T.] numerous foreign scholars were invited to Saint Petersburg - Germans in particular. Since 1725 scholars dynamically began to arrive in Petersburg, signing contracts regulating the duration of their service, apanage and accommodation" (GARCZYK 2015:24).

The peak of Russian intellectual development occurred between 1890 and 1917 this period has been referred to as the "silver age of Russian culture" by historians (LikHaChev 2011:5). Saint Petersburg was the epicenter: "science gave birth to firstclass scholars here [in Saint Petersburg - O.T.]. [...] In oriental studies there was a vast array of scholars whose research involved the Arabic world, China, India, Turkish, Iranian, Indian and Finno-Ugric peoples. The Russian Academy of Sciences raised scholars researching the Caucasus, the northern peoples representing unknown language families. Russians studied Lithuanian, Latvian, Estonian, and Tatar languages, they examined the lives and languages of Aleuts and Polynesians" (LikHaCHEv 2011:6). In the field of Mongolian studies the contribution of Russian orientalists, particularly

4 These traditions are considered exceptional in Russian urban life; however the special character of peterburgskie guliania festivals were related to Saint Petersburg's close ties with Europe (KONECHNYI 1989; Keller 2001). Peterburgskie guliania were described in the following way: "Twice a year an entertainment park was established at Admiralteiski square which stretched throughout one and a half kilometer, as far as Dvortsovoi and Isaakovskoi squares. It was located along two lines on which slides were placed opposite each other. The so-called 'balagany'[theatre stages - O.T.] were placed nearby" (KONECHNYI 1989:27) at which one could see "an albino in half-savage outfit, who speaks English, German, French and Italian, dances of indigenous people from Australia, Africa, North and South America, a giant from Finland, a one-handed cripple who writes with feet" (KoNECHNYI 1989:31). At the end of the $19^{\text {th }}$ century, performances of this genre were replaced by theatres. 
those associated with the University of St. Petersburg, are undoubtedly considered to be the earliest and greatest in Europe.

It is worth noting that the intellectuals from $19^{\text {th }}$-century Russia were not devoid of theories grounded in the colonial era, including theories on race and ethnocentrism. As Aleksander Bukh states, "the European concept of race arrived in Russia in the mid-19 century. However, its dimension turned out peculiar in relation to Asia, due to historical and territorial ties between Russians and Asians" (BUKH 2014:178). In contrast to other colonial empires, Russia did not possess overseas colonies. Moreover, "metropolis and peripheries became one space here, which created a peculiar character of this area" (ToLZ 2013:43). Without detailed references regarding racial theories which would require a separate article, I only wish to emphasize that Russia did not have colonies in Africa and this translated into certain consequences: "[the] positional 'specifics' of Russian expansion, an African 'lack' in its imperial mapping of the world, has spun off into the view that for this reason Russia has been less inclined to racism and 'racialist' ideas played a relatively minor role in Russia's imperial practices and intellectual traditions" (DAvid-Fox et al. 2006:8, quoted in Novikova 2013:2).

Meanwhile, the colonial ambitions of the tsars aimed at extending the sphere of Russian influence towards inland Asia, particularly towards China which resulted in the fact that Russian tsars were profoundly interested in all research in Asia and used every opportunity to support it (ANDREEV et al. 2018:34). The operations of the Russian Geographical Society (RGO) $)^{5}$ registered in Saint Petersburg, were conducted under the auspices of the Tsar, as the institution enjoyed the support of the House of Romanovs since the moment of its establishment in 1845 (ERMAKOvA 2015:120). The organization's charter of 1898 states that the goals of its operations included collecting, preparing and distributing geographic, ethnographic and statistical data concerning Middle and Eastern Asia. The prepared materials were to be distributed in the form of public lectures during RGO gatherings, in the form of serial publications and periodicals as well as through the publicizing notes and records of scholars (RGO Charter, dated 1898, quoted in ERMAKOVA 2015:120).

Alongside the renowned 'imperial expeditions' of the RGO, the Russian Orthodox Church's Ecclesiastical Mission (Russkaia dukhovnaia missia), established in Beijing in 1715, also actively conducted fieldwork. The mission operated for the duration of two centuries, until 1954 (ANDREEV et al. 2018:9). Nonetheless, it was through the expeditions to inland Asia organized under the banner of the Imperial Russian Geographical Society that the participants attained fame. In the words of Nikolai Przhevalskii (1839-1888): "we have accomplished our task to the very end, we have passed through and explored those places in Central Asia, where the foot of a European has never stepped" (quoted in ANDREEV et al. 2018:1). An interesting character from that period worth mentioning here was the RGO member Gombodzhab Tsybikov (1873-1930) - Buryat by origin, a graduate of the Department of Eastern Languages at the University of Saint Petersburg. In 1899 and 1901, Tsybikov managed to enter Lhasa dressed as a Mongolian pilgrim. At that time Lhasa authorities banned foreigners from entering Tibet, with the exception of Buddhist pilgrims (ANDREEv et al. 2018:36; ERMAKOvA 2015:121-125). Tsybikov was supplied

5 Russkoe Geograficeskoe Obszestvo (RGO), renamed as the Imperial Geographical Society (IRGO) from 1849 onwards. 
"with French-made portable cameras and glass plates by the RGO which enabled them to take many pictures of Lhasa, its environs, and Tibet's major monasteries, sanctuaries and historical sites, the earliest ones ever taken by travelers in the noman's land" (ANDREEv et al. 2018:36). Tsybikov is considered to be the first scholar to conduct a comprehensive study of Tibet using the European scientific framework (Tolz 2013:204).

Another institution related to researching Asia was the Russian Committee for Middle and East Asia Exploration (Russkii Komitet dlia Izuchenia Srednei i Vostochnoi Azii). Established in 1903, this institution focused on research in the fields of history, archaeology, linguistics and ethnography. The Committee included both representatives of scientists (among others, orientalists Sergei F. Oldenburg and Feodor I. Shcherbatskoi) and representatives of the following ministries: Foreign Affairs, War, Finance, Internal Affairs and National Education (ERMAKOva 2015:125).

In accordance with the spirit of the colonial era, Russian orientalists made attempts to study peoples and their cultures using scientific methods. Therefore, ethnography as a scientific discipline began to emerge as increasingly important. As suggested by Aleksandr I. Andreev: "the IRGO contributed significantly to making ethnography a scientific discipline; the Society, from its very beginning, included an ethnographic department (along with the departments of mathematical geography, physical geography and statistics). Moreover, the IRGO was the first scientific society in Europe to have set itself the task of studying various ethnic groups inhabiting the multi-ethnic Russian Empire" (ANDREEV et al. 2018:43). This ethnographic research, "apart from its great cognitive value, also shaped popular images of unknown lands and peoples for a vast audience - the readers of travel literature and visitors to the travelers' public lectures and to their exhibitions of collected materials (zoological, botanic, and ethnographic)" (ANDREEV et al. 2018:42).

When travelling inland in Asia, the RGO members spread information about the power of Russia and the 'White Tsar' - the defender of Russia, Muslims and Buddhists (ANDREEV et al. 2018:42). In this manner, field exploration was accompanied by a certain form of pro-Russian agitation at the lowest echelon. Such contacts count as the process of gradual extension of intercultural communication. These activities allowed Russia to discreetly yet systematically expand her sphere of influence throughout new territories and towards people inhabiting western peripheries of China (ANDREEV et al. 2018:42).

According to Vera Tolz, it was due to the intense development of oriental studies in Russia that a faster political and cultural integration of the peripheries was possible, when compared to empires in possession of overseas colonies (ToLz 2013:42-43). In her book entitled Sobstvennyi Vostok Rossii (Russia's Own Orient), Tolz describes the activity of orientalists (vostokovedy) associated with the dean of the Department of Eastern Languages at the University of Saint Petersburg, Viktor Romanovich Rozen (1849-1908). The researcher describes the activity of some students of Rozen, prominent orientalists including Vasilii Vladimirovich Bartol'd (researcher of Turkestan), Nikolai Iakovlevich Marr (researcher of Caucasus) as well as two researchers of Buddhism: Sergei Fiodorovich Oldenburg and Feodor Ippolitovich Shcherbatskoi (ToLz 2013). In the words of Tolz: "in 1880s Rozen as a professor at St. Petersburg University developed a clear strategy for creating a new school of Russian Oriental Studies imbued with his vision. At the top of his agenda was a plan to promote the study of Russia's 'own Orient', 
most notably its Muslim and Buddhist Communities ${ }^{6}(\ldots)$ Rozen also argued that scholars should focus on the nodes (uzly) of cultural, political, and economic interaction between peoples of different ethnic origins, languages, and religions. In pursuing these research questions, scholars were expected to avoid drawing a simple dichotomy between the peoples of East and West. Instead, they were expected to see 'Russian culture' as a space where the East and the West met" (Tolz 2013:21-22).

Tolz considers these orientalists 'guardians of the Empire', who, nonetheless, recognized the needs of self-identification among national minorities, formulated in terms of cultural autonomy rather than political separatism. They believed that strong ethnic and cultural identification may actually reinforce, and not debilitate, the ties between the ethnic minorities and the Empire (ToLz 2013:297). Orientalists suggested an inclusive definition of 'Russianness', ${ }^{7}$ which enabled "the possibility of forming a multiethnic nation, based on a civic principle of political and social integration, which did not require linguistic and cultural homogeneity" (SANBORN, quoted in Tolz 2013:128). This pertained above all to the inhabitants of Caucasus, Central Asia and Siberia, whose sense of local identity was rather weak, as opposed to other ethnic groups, especially those inhabiting territories located next to the western borders of the Empire (ToLz 2005:139).

Tolz also stresses that the majority of orientalists from the Rozen School were of nonRussian origin. ${ }^{8}$ She points to the fact that these orientalists offered new methodological approaches in research on the cultures they studied. They rejected the East-West dichotomy as fiction generated by European imagination and criticized a strong conviction of the West about the superiority of Western European norms and practices. Moreover, they criticized the tendency to categorize different cultures according to Western European standards (Tolz 2013:300).

Furthermore, Tolz claims that the Rozen School developed a research methodology, on the basis of which empirical data from ethnographic or linguistic sources could be processed. Sources derived from non-academic experts, such as military men, state officials or clergy, were rejected or analyzed very critically. Scholarly orientalists saw them as based on non-objective premises: Christian, Eurocentric or racial (Tolz 2013:23).

Based on the works of orientalists (e.g. Nikolai Ia. Marr, Sergei F. Oldenburg, Feodor I. Shcherbatskoi), Vera Tolz demonstrates their belief in the leading role of Russian science in overcoming the East-West dichotomy and illustrating a different path of cultural approximation (ToLz 2013:155-192). The critique of European science was mostly directed towards German and Austrian research, primarily concerning the relations between orientalism and European imperialism, where science allegedly appeared in the role of a 'humble servant' to the colonial empires (Tolz 2013:145). In this way, Tolz questioned the famous critique offered by Edward Said in Orientalism (1978) concerning the origins of European oriental studies, established to generate knowledge

${ }_{6}$ The concept of 'Own Orient' involves the territories of Caucasus, Turkestan, non-European communities of East and West Siberia, the Volga Region as well as the states and communities bordering the Russian Empire (Tolz 2013:17).

7 The concept of 'Russianness' has raised controversy until the present day. It was the axis of the $19^{\text {th }}$ century disputes between pro-Westerners (zapadniki) and Slavophiles (slavianofily), it also constituted the ideological foundation of the Eurasian movement.

8 Viktor R. Rozen, Vasilii V. Bartol'd and Sergei I. Oldenburg were of German origin, Nikolay Ia. Marr came from a Scottish-Georgian family (Tolz 2013:29-30). 
enabling ruling and dominance over colonial peoples. Tolz demonstrates that Russian involvement in oriental studies were of a different nature than that of Great Britain or France, analyzed by Said (ToLz 2013:130). In her opinion, the main objective of the oriental studies propagated by Russian scholars consisted of getting acquainted with the studied peoples using scientific methodologies and bringing the ideas of Enlightenment to them (Tolz 2005).

According to Tolz, research methods employed by Russian orientalists contributed to strengthening the position of local peoples inhabiting the eastern and western peripheries of Russia in the first three decades of the $20^{\text {th }}$ century, as compared to that in different empires where the production of an analogical type of knowledge took place (ToLz 2013:299). It should be stressed that not all ethnic minorities in the Russian Empire could count on a position such as Buryats, but, as Tolz demonstrates in her book (see: Chapter V), their case can be defined as one of the most successful examples of cooperation between Russians and the representatives of ethnic minorities.

The critique of 'Western science' reinforced anticolonial rhetoric related to the changes caused by the October Revolution (1917). Even though the revolution aimed at a complete reorganization of the state, from the perspective of oriental studies the assumptions formed during the imperial era remained unchanged for a relatively long period of time (Tolz 2013). Nationalist policies of the Bolshevik authorities in the 1920s, known as korenizatsiia, ${ }^{9}$ were inspired by the visions of pre-revolutionary Russian orientalists as well as the intellectual traditions of the Russian Empire (Tolz 2005).

In Saint Petersburg after the October Revolution, opportunities still existed for publically presenting orientalist knowledge. For example, in 1919 "The First Buddhist Exhibition" took place, organized by the director of the Asian Museum, Sergei F. Oldenburg (Rozen's student). It featured not only iconographic materials or researchers' collections related to Buddhism in Asia but also a series of lectures on Buddhism and publications of scientific articles (RUDOI 1994:392-402). Tolz's account of the social reception of the achievements of the orientalists in Saint Petersburg reads: "in the first three decades of the $20^{\text {th }}$ century the cultural elite undoubtedly constituted appreciative audience for the representatives of oriental studies. Famous writers and painters, such as Andrei Belyi, Maksimilian Voloshin, Aleksandr Blok and Nikolai Rerich, similarly to the representatives of broader circles of the Russian elite, enchanted by theosophy and Buddhism, carefully read the writings of Russian orientalists" (Tolz 2013:111).

\footnotetext{
9 Korenizatsiia - roughly translated as 'indigenization' - "a set of policies aimed at developing and promoting national identity: the recruitment and promotion of members of the local nationality in the Communist Party and Soviet system; positive discrimination in other areas of employment; the creation of standardization of national languages and scripts, together with national cultures based on earlier writers and folk traditions; the extension of local self-rule for national minorities outside the republics through system of national Soviets; and building up a network of national schools with instruction in the mother tongue for all non-Russians" (SмIтн 2006:498).
} 


\section{THE BUDDHIST DATSAN IN SAINT PETERSBURG}

Prior to presenting the history behind the establishment of the Buddhist temple in Saint Petersburg, it is worth mentioning that the Russian Orthodox Church, despite having represented state religion with a privileged status, did not exclude the coexistence of other religions within the Empire. According to Bartłomiej Garczyk, "the Tsar officially recognized the existence of other, non-Orthodox religions. However, the condition of their recognition was based on the dissenters' absolute political loyalty towards the authorities and ban on any kind of activity that could negatively affect the interest of the state carat" (GARCZYK 2015:120). Moreover, one would do well to keep in mind that Islam, Judaism and Buddhism, alongside Protestantism and Catholicism, were classified as 'priznannye terpimye', i.e. denominations tolerated by the state (SAFONOV 2017:96-97). At the beginning of the $20^{\text {th }}$ century, and under the influence of the October Manifesto of 1905 a certain liberalization of religious life in Russia could be observed. The ordinance of the State Duma dated May 26, 1909, was of particular significance in this respect as it enabled Russian citizens to convert from the Christian religion (not excluding the Orthodox Church) to other denominations (ANDREev 2012:7). Such conditions can be considered favorable with respect to the establishment of both the Buddhist church and temples of other confessions in St. Petersburg. A history similar to that of the one associated with the Buddhist temple, is the account of the Peterburgskaia Sobornoia Mechet' mosque which was erected in the capital of the Russian Empire between 1910 and 1913 (STECKevich 2002:323). The mosque was used by Muslims, mainly successors of Tatars and Bashkirs from the Volga Region, who were involved in the construction of the city of Saint Petersburg in the $18^{\text {th }}$ century (GARCZYK 2015:104). The mosque currently counts as one of the most important Muslim centers in Russia. ${ }^{10}$

According to Aleksandr I. Andreev, a historian of Saint Petersburg and the author of numerous publications on the history of the local Buddhist temple, the main initiator of its establishment was Buryat lama Agvan Dorjiev, the emissary of the $13^{\text {th }}$ Dalai Lama of Tibet. In 1906, Dorijev requested permission from Tsar Nicholas II to build a Buddhist temple in Saint Petersburg. He justified his initiative with the religious needs of the Kalmyk and Buryat diasporas inhabiting the capital (according to the population census of 1910 a total of 184 Buddhists were registered in Saint Petersburg - ANDREEv $2012 \mathrm{~b}: 14)$. The main reason of the initiative however, was tightly bound with competition for influences in Tibet between Russia and Great Britain. Dorjiev was one of the most important people in the Dalai Lama's surroundings and established a group of political Russophiles close to him. The group was involved in lobbying for the approximation between Tibet and Russia where - as claimed by the Buryat lama - "Buddhism is protected by 'The White Tsar' himself' (ANDREev 2012a:8). The history of the Saint Petersburg Buddhist temple suggests that, regardless of the final arguments determining the final decision of its establishment, without the personal involvement of charismatic Dorjiev and a number of other individuals related to Buddhism at the time, the datsan might not have been erected.

10 Slightly earlier, in 1893, the Grand Choral Synagogue was founded, which was related to the history of Jews from Saint Petersburg (GARCZYK 2015:150-151). 
The collection of funds necessary for erecting the temple lasted for many years. Contributors included the highest hierarchs of Tibetan Mongolian Buddhism, worshippers from Buryatia and Kalmykia, diasporas residing in St. Petersburg as well as Buddhists of other nationalities (Russians, Chinese, Japanese, etc.) (ANDREev 2012b:53). On the list of donors Piotr Aleksandrovich Badmaev should be emphasized. He was of Buryat origin and arrived in Saint Petersburg in the 1860s to visit his brother, who worked as a physician of Tibetan medicine and ran a pharmacy distributing herbs of his own production. Badmaev graduated from the Department of Eastern Languages in Saint Petersburg and the Medical Academy (founded in 1799). Badmaev's nephew, Włodzimierz Badmajeff, writes about his uncle in the book entitled Chi szara badahan: "he studied eastern medicine under the guidance of his brother and in Tibet, taught by the most renowned Tibetan scholars. Having studied both eastern and western medicine he translated Zhud-shi [a classic textbook of Indian and Tibetan medicine - O.T.] into Russian and supplemented it with numerous comments and footnotes" (BADMAJEFF 1929:12). He became the personal physician of Tsar Nicholas II and other members of his family; he worked at the Ministry of Foreign Affairs and was involved in social activities targeting the integration of Mongolia, Tibet and China with Russia (BADMAJEFF 1929:5). Like the majority of Buryats at the time, he was baptized in the Orthodox Church, which was no obstacle for him to donate money and support the establishment of the datsan (ANDREEv 2012b:53).

A crucial role in the establishment of the Buddhist temple was played by orientalists related to the Rozen School and specialists studying Buddhism and Mongolian peoples including: Vasilii V. Radlov, Sergei F. Oldenburg, Feodor I. Shcherbatskoi, Wladyslaw L. Kotwich, Andrei D. Rudnev. Some of them were not scholars, but the intellectuals, who became interested in the East as a result of ideological trends popular in Western Europe at the time. On account of these factors, from the $19^{\text {th }}$ century onwards the East began to be perceived as an alternative to the European model of life in various social spheres ranging from economy to art. General interest in the East reached its peak in the period between 1880 and 1920 (MACKenZIE 1995:330). Buddha's teachings spread in major European cities such as London, Paris, Berlin, Rome and Vienna (Andreev 2012b:17). These teachings particularly referred to the Hinayana Buddhist tradition which originated from southern India (ANDREEv 2012b:17). In this sense, as stated by Andreev "the Russian capital at the end of the $19^{\text {th }}$ and the beginning of the $20^{\text {th }}$ century became a meeting point of two different Buddhist traditions, as it differed from the reformed Tibetan Mongolian school of Buddhism, traditionally worshipped by the Russian Buryats and Kalmyks" (ANDReEv 2012b:19). The neo-Buddhists in Petersburg included representatives of aristocracy and the so-called 'liberal intelligentsia' as well as the military elites. Among them was prince Eduard E. Ukhtomski - a scholar, diplomat and traveler who published one of the most popular newspapers in the city entitled Sankt Peterburgskie Vedomosti [S.Peterburgskiia Vedomosti - O.T.]. He was the one to organize Dorijev's audience with Tsar Nicholas II (ANDREEv 2012b:22).

Apart from overcoming administrative and financial obstacles, Dorijev and his allies had to face people hostile towards the datsan, namely the representatives of the Russian Orthodox Church. The church archives from the beginning of the $20^{\text {th }}$ century contain texts vilifying the temple and the initiators of its construction (see: NEZDOROvOE IAVLENIE 1911:145-151; PeKINETs 1915 et al.). A list of active opponents of the idea 
of datsan construction included the Orthodox Church hierarchs, rector of the seminary in Połtawa and archimandrite ${ }^{11}$ Varlaam (full name: Riashchentsev Viktor Stepanovich) who wrote about the temple in the categories of the "the advent of the dark times and the Antichrist" (VARLAam 1910).

Though the first references of the temple convey information on plans of erecting a small prayer-house (for 100-120 people), the later ones were already connected with the image of datsan, viewed from the perspective of the inhabitants of the city: "the few reporters who visited the temple were astonished to see instead of a modest and unpretentious prayer-house a grand, majestic and yet bizarre edifice of the Buddhist pagoda" (ANDREEV 2012a:60). According to Andreev: "the architectural design of the temple was elaborated by Russian architects and they aimed to restore the main feature of Tibetan Buddhist architecture, but they also wanted the temple to have some features of European style. The famous painter Nicolas Roerich [Nikolai Rerich - O. T.] designed the stained glasses" (ANDREEV 2012a:60). To the best of our knowledge, there was no tradition of stained glasses in temples, but that of Rerich's presented the main Buddhist symbols.

The first public worship in the temple was held while it was still under construction. It was conducted on February 21, 1913, on the day when all of Russia celebrated the $300^{\text {th }}$ anniversary of the House of Romanovs. It was commonly believed among Buddhists (not only in Saint Petersburg), that the construction of the temple was only made possible through the unfailing grace of the 'White Tsar' towards them. At the same time, the celebration of anniversary of the House of Romanovs, was also conducted in the local synagogue and mosque (ANDREEV 2012b:63).

The second ceremonial worship took place in June of 1914 when two Buddha statues from Siam (Thailand) were brought to the temple where they were blessed. The Siamese king Chulalongkorn's (Rama V) involvement in the temple was related to the fact that his son prince Chakrabon studied in St. Petersburg and had a Russian wife (ANDREEV 2012b:71). This event must have been important for the community of St. Petersburg, some newspapers even published pictures of the statues and participants of the ceremony (ANDREEV 2012b:76).

In the first years following the opening of the temple one of the most frequent rituals was the zhud khural - a prayer in the intention of 'victory of the Russian weapons' in the World War I (ANDREEv 2012b:76). This demonstrates how the hosts of the temple strove for harmonious co-existence in the Russian Empire.

The consecration of the temple was held in August of 1915. It was conducted by Dorjiev. A staff of ten monks from Buryatia and Kalmykia were approved by the Russian authorities to officiate at the temple. On this occasion, special coins were issued in the form of characteristic tokens-medals with the image of the datsan and its name in Tibetan and Mongolian on the reverse side (ANDREEV 2012a:25).

Soon after the opening of the temple, the shortage of food as well as the general condition of poverty in Saint Petersburg caused by World War I made it hard for the lamas to remain in the city. Consequently, most of them returned to their homelands in Kalmykia and Buryatia. After 1917, the building was ransacked, taken over and damaged by the Red Army detachment. The temple was forced to close down. Finally, at the end

11 An honorary title of the Russian Orthodox Church. 
of 1920s, after an almost 10-year break, the temple was reopened. Once more, a small group of Mongolian and Tibetan monks could live in this temple and conduct traditional prayers (khural). As Andreev writes: "old timers recall, in 1930 the temple was the scene of a most impressive and colorful performance, the mystery dance of Tsam. For that purpose, at the invitation of Dorjiev a large group of monks came to Leningrad from the Aga temple, one of the largest and oldest in Buryatia" (ANDREev 2012a:33). Despite the Stalinist terror and fear, ceremonies at the temple attracted the residents of Saint Petersburg. Tsam constitutes an incredibly spectacular visual and artistic formula - a theatricalized religious story performed to the rhythm of Tibetan music by monk actors, wearing colorful masks and outfits. Another ritual, equally attractive for city residents, consisted of the ritual of creating mandalas, meaning building diagrams symbolizing the universe with the use of colorful grains of sand (FIODOROva 2002:334). This is one of the major meditative practices (it portrays the gate to 'entering (the) Cosmos') and one of the most essential practices in the activity of datsans, also performed during major state celebrations.

The reactivation of the datsan's activity did not last for a long time. Repressions of the Stalinist period affected Dorjiev, who was arrested by the People's Commissariat for Internal Affairs (NKVD) and died in prison in 1938. In the same year, by the ordinance of the Leningrad City Soviet, the temple was passed on to the Workers Union. During World War II, the datsan housed a radio station. In the 1950s, a zoological laboratory was established in the building. It was no earlier than 1990 that, in the spirit of pierestroika, the Buddhist community was officially recognized by the state authorities and, as a result, the datsan was returned to the Buddhists.

Since its very establishment this 'exotic' Buddhist temple, located at the quiet left bank of the Neva river in the northern district of Staraia Derevnia inevitably attracted the attention of Saint Petersburg residents. Detailed descriptions of the datsan demonstrate the image of a majestic Buddhist temple with a colorful interior and gilded Buddha statues at the altar. The building was inhabited by Buryat and Kalmyk monks of the Tibetan Buddhist tradition, who were ethnically and culturally different from the residents of Saint Petersburg at the time. ${ }^{12}$ As was the case in all Tibetan Buddhism temples, the monks probably prayed in a half-singing manner, accompanied by the sounds of 'exotic' instruments (made from, among others, human tibia bones). The sounds of the instruments were surely unusual for European ears. The smell of Indian incense sticks, an indispensable element of Buddhist temples, was present inside. The combination of these elements must have created an extraordinary spectacle for the city inhabitants at the time.

Importantly, however, the datsan had to blend in with the urban landscape that was characteristic of the style prominent at the turn of the $20^{\text {th }}$ century. In terms of the functional aspect, the temple was built based on the Tibetan tsogchen dugana, which combined the worship part with a living space for monks and visitors. In order to visualize this order, it is prudent to note the following details: "next door in the Buddhist hostel usually resided the students from Mongolia, Tibet and occasional visitors from Buryatia and Kalmykia. In the early 1930s two small shops were opened on the ground floor of the building, selling foodstuffs like rice, herbs, spices, and various Buddhist paraphernalia including incense

12 According to the public census of 1910 , Russians constituted $82 \%$ of Saint Petersburg's population (GARCZYK 2015:31). 
sticks, painted and sculptured sacred images. Here anyone could come in and address his request directly to Buddha, by writing it on a scrap of paper" (ANDREEv 2012:71).

All in all, the founding and history of the datsan in Saint Petersburg is tightly bound to the activity of orientalist scholars, liberal intellectuals and initiators of the temple's establishment. It was due to their visions of integrating people of Russian and nonRussian origin that the temple was built. An essential role was played by peculiar conditions in the city at that time, in the process of the establishment of the datsan. In the cosmopolitan and multicultural Saint Petersburg, liberal intellectuals constituted an important voice. Research, social and promotional activity at scientific, educational and state institutions enabled creating theoretical background and methodologies for examining "the Other".

The goal and mission formulated in the spirit of modernity during the early $20^{\text {th }}$ century which was pursued by the datsan founders, is present to this day. The Gunzenchoinei temple hosts not only traditional prayers, rituals and ceremonies of healing predominantly conducted by resident lamas, graduates of the Ivolginski Buddhist Institute Dash Choinkhorling in Buryatia but also, invites western Buddhist scholars, who offer lectures in Buddhist philosophy and meditation techniques; thus propagating the teachings of both the Gelugpa as well as other schools. The temple has become a place where one can encounter Tibetan, Buryat, Mongolian and Kalmyk cultures and traditions. The temple is also involved in charity and educational initiatives. Moreover, the lamas of the temple work towards 'interreligious and interethnic cooperation'. ${ }^{13}$

\section{CONCLUSION}

From the moment of its establishment, Saint Petersburg was both an important political center of the tsarist Russia but also a significant cultural center. It became a peculiar 'platform' spreading Enlightenment ideas, technical news and Western European thought to other Russian territories. Similar to that of a mosque or a synagogue, the Buddhist temple described in the present article was erected in the spirit of the modern era.

Western formulas of encountering the 'exotic' Other, such as ethnographic shows, circuses, variété, as well as the local urban entertainment in the form of gulianii, which functioned in Saint Petersburg during the $18^{\text {th }}$ century and the end of the $19^{\text {th }}$ century, were popular among the city residents, however, not all of them survived the test of time. The Buddhist temple which functioned as a different type of space for encountering "Others" - namely, Buryat and Kalmyk monks - survived, even though the content and form of contact differed significantly from that of those mentioned above.

Apart from the active involvement of numerous individuals, the establishment of the temple was facilitated by a long tradition of the Russian tsars in supporting research institutions, due to which oriental studies could develop. Due to the socio-political activity of the orientalists, students of different origins (inorodcy) were allowed to study in Saint Petersburg's universities and were thus, able to actively participate in the social life of the city.

13 Datsan Gunzechoinei: www.dazanspb.ru (accessed March 11, 2019) 
It is no accident then, that the Buddhist temple was erected precisely in the very city of Saint Petersburg. The city functioned as a 'state within a state', being the capital, metropolis, seat of the tsar, establishing its own rules for functioning and intercultural contact; which was not characteristic of the remaining part of the Russian Empire and most probably, impossible to implement outside the peculiar conditions of the city.

\section{REFERENCES CITED}

Alekseev-Apraksin, Anatolii Mikhailovich

2008 Buddizm v Peterburge. Istoriia i sovremennost'[Buddhism in Saint Petersburg. History and Modernity]. Sankt-Peterburg: Olearius Press.

ANDREEv, Aleksandr Ivanovich

1992 Buddiiskaia sviatynia Petrograda [The Buddhist Shrine of Petrograd]. UlanUde: EkoArt.

2012a Sankt-Peterburgskii Datsan [The Saint-Petersburg Datsan]. Sankt-Peterburg: Nestor-Istoria.

2012b Khram Buddy v Severnoi Stolitse [The Temple of Buddha in Northern Capital City]. Sankt-Peterburg: Nartang izdanie A. Terentieva.

AndreEv, Aleksandre - Baschanov, Mikhail - Yusupova, Tatiana

2018 The Quest for Forbidden Lands: Nikolai Przhevalskii and his Followers on Inner Asian Tracks. Leiden - Boston: Brill.

BADMAev, Piotr Aleksandrovich

2001 Za kulisami tsarizma [Behind the Scenes of Tsarism]. Minsk: Khardvest- AST.

BADMAJEFF, Włodzimierz

1929 Chi szara badahan. Zasady medycyny tybetańskiej [Khi, szara, badakhan. Principles of Tybetan Medicine].Warszawa: Sowa - druk na życzenie (reprint).

BukH, Aleksander

2014 National Identity and Race in Post-revolutional Russia: Pilniak's Travelogues from Japan and China. In Kowner, Rotem - Demel, Walter (eds.) Race and Racism in Modern East Asia. Western and Eastern Contructions, 177-198. Leiden - Boston: Brill.

CzARneCKa, Dominika

2018 'A w niedzielę szło się oglądać ludzi’. Pokazy etnograficzne we wrocławskim ogrodzie zoologicznym 1876-1930 ['And on Sunday we Went to Watch the People.' Ethnographic Shows in the Wroclaw Zoological Garden between 1876 and 1930]. Etnografia Polska 62(1-2):183-198.

DAVID-Fox, Michael - Holquist, Peter - Martin, Alexander

2006 Russia's Orient, Russia's West. In DAVID-Fox, Michael - Holquist, Peter - Martin, Alexander (eds.) Orientalism and Empire in Russia, 3-22. Bloomington, Indiana: Slavica.

DEMsKi, Dagnosław

2018a 'Spoglądając wstecz'. Wystawa szczepów z Doliny Nilu w Poznaniu, 1914 ['Looking back.' The Exhibition of the Tribes from the Nile Valley in Poznań, 1914]. Etnografia Polska 62(1-2):199-219. 
2018b Azja w cudzych oczach. „Pokazy” ludów azjatyckich na ziemiach polskich na przełomie XIX i XX wieku" [Asia in Other's Eyes. 'Shows' of Asian Peoples in the Polish Lands at the Turn of the $20^{\text {th }}$ Century]. In BaraniECKA-OlszewsKa, Kamila - KABZIŃSKA, Iwona - TANGAD, Oyungerel (eds.) Lokalne i globalne perspektywy azjanistyczne. Księga jubileuszowa dla Profesora Stawoja Szynkiewicza, 295-308. Warszawa: Wydawnictwo IAE PAN.

ERmaKova, Tatiana Viktorovna

2015 Podhod Sankt-Peterburgskoi buddiiskoi shkoly k izucheniiu buddiiskikh monastyrei Tibeta (1890-1910g.g.) [Methodological Approach of Saint Petersburg Buddhist School to the Studies of Buddhist Monasteries of Tibet]. In Popova, Irina Fedorovna - BADMAev, Vladimir Vladimirovich - UsPensKY, Vladimir Leonidovich - Zorin, Aleksander Valerievich - Sizova, Alla Alekseevna (eds.) Uchenie Buddy w Rossii, 250 let instytutu Pandito Khambolam, 119-133. Sankt Peterburg: Peterburgskoe Vostokovedenie.

FIODOROVA, Mariia Vladimirovna

2002 Buddizm. Osnovy veroucheniia [Buddhism. The Basics of Creed]. In Bessonov, Nikolay (ed.) Mnogonatsionalnyi Peterburg. Istoriia, religii, narody, 325-341. Sankt-Peterburg: Iskusstvo-SPB.

GARCZYK, Bartłomiej

2015 Wielonarodowy Petersburg. Nierosyjska historia miasta, 1703-1917 [Multinational Saint Petersburg. Non-Russian History of the City, 17031917]. Poznań: Wydawnictwo Poznańskiego Towarzystwa Przyjaciół Nauk.

KeLLER, Elena Ėrvirovna

2001 Prazdnichnaia kul'tura Peterburga: ocherki istorii [Festive Culture of Petersburg: History Outlines]. Sankt-Peterburg: Izdatel'stvo Mikhailova V.A.

KoneChNyI, Albin Mikhailovich

1989 Peterburgskie narodnye gulianiana maslenoi i paskhalnoi nedeliakh [Folk Festivals in Saint Petersburg during the Pancake and Easter Weeks]. In Yukhniova, Natalia Vasil'evna (ed.) Peterburg $i$ gubernia. Istoriko etnograficheskoe issledovania, 21-52. Leningrad: Nauka.

LiKHACHEV, Dmitrii Sergeevich

2011 Peterburg. Khudozhestvennaia zhiz'n' 1900-1916. Fotoletopis' [Saint Petersburg. Artistic Life in 1900-1916. Photochronicle]. Sankt-Peterburg: Iskusstvo-SPB.

MacKenZIE, John

1995 Orientalism. History, Theory and the Arts. Manchester: Manchester University Press.

NAMKHAI, Norbu

2001 Krysztat $i$ ścieżka światła (sutra, tantra i dzogczen) [Crystal and a Path of the Light (sutra, tantra and dzogchen)]. Kraków: Wydawnictwo A.

NeKrylova, Anna Fiodorovna

1988 Russkie narodnye gorodskie prazdniki, uveseleniia $i$ zrelisha [The Russian Urban Folk Festivals, Amusements and Spectacles]. Leningrad: Iskusstvo. Leningradskoeotdelenie. 
NIEZDOROVE IAVLENIE

1911 Nezdorovoe iavlenie. K postroike buddiiskoi molel'ni v SPburge [Abnormal occurrence. On the Erection of Buddhist Temple in Saint-Petersburg]. Otdykh khristianina (1):145-151.

Novikova, Irina

2013 Imagining Africa and blackness in the Russian empire: from extra-textual arapka and distant cannibals to Dahomey amazon show - live in Moskow and Riga. Social Identities 19(5):571-591.

PEKINETS

1915 Buddijskoe kapishsche v Petrograde i pravoslavnyi khram v Pekine [A Buddhist Shrine in Petersburg and an Orthodox Christian Temple in Beijing]. Kitaiskii blagovestnik (13/14):1-4.

RudoI, Valerii Isaevich

1994 Buddiiskaia vystavka v Peterburge [The Buddhist Exhibition in Saint Petersburg]. In OstrovskaYa, Elena Petrovna - RUdoi, Valerii Isaevich (eds.) Buddiiskii vzgliad na mir, 392-402. Sankt-Peterburg: Andreev i synovia.

SAFONOV, Aleksandr Aleksandrovich

2017 Gosudarstvo $i$ konfesii v pozdneimperskoi Rossii. Pravovye aspekty vzaimootnoshenii [State and Confessions in Late Imperial Russia. Legal Aspect of Mutual Relationship]. Moskva: Prospekt.

SMith, Jeremy

2006 Non-Russians in the Soviet Union and after. In SunY, Ronald Grigor (ed.) The Cambridge History of Russia, vol. 3, 495-521. Cambridge: Cambridge University Press.

SteTSKevich, Tatiana Aleksandrovna

2002 Kratkii ocherk istorii islama i zhiz'n' musul'manskoi obshchiny Peterburga [Brief Outline on Islam and Life of Muslim Community of Petersburg]. In Bessonov, Nikolay (ed.) Mnogonatsionalnyi Peterburg. Istoriia, religii, narody, 310-324. Sankt-Peterburg: Iskusstvo-SPB.

Tolz, Vera

2005 Orientalism, Nationalism, and Ethnic Diversity in Late Imperial Russia. The Historical Journal 48(1):127-150.

2013 'Sobstvennyi Vostok Rossii.' Politika identichnosti $i$ vostokovedenia $v$ pozdneimperskii i rannesovetskii period [Russia's Own Orient. The Politics of Identity and Oriental Studies in the Late Imperial and Early Soviet Periods]. Moskva: Novoe literaturnoe obozrenie.

VARLAAm (RiashCHENTSEv, Viktor Stepanovich)

1910 Buddiiskoe kapishchev Peterburge [A Buddhist Shrine in Petersburg]. Poltava: Elektr. tip. L.I. Markovicha, Bulvar Katlarovskago. 


\section{INTERNET SOURCES}

ZAPESOTSKII, Aleksandr Sergeevich - MiKhaILOv, Aleksandr Andreevich

2011 Peterburg kak kul'turnyi fenomen rossiiskoi istorii [Saint Petersburg as a Cultural Phenomenon of Russian History]. http://culturolog.ru/content/ view/909/12/ (accessed February 20, 2018).

Datsan Gunzechoinei, https://dazanspb.ru/ (accessed March 11, 2019).

Oyungerel Tangad (Ph.D.) is a cultural anthropologist with long-term ethnographic interests in Mongolia. Her research activity is predominantly focused on cultural aspects of social phenomenon in Mongolia. The issues of cross-cultural translation methodology applied in Mongolian studies area fall in scope of her particular interests. She is an author of the book: Scheda po Czyngis Chanie. Demokracja po mongolsku (2013) [Heritage of Chinggis Khaan. Mongolian-style Democracy]; she also authored several articles on contemporary Mongolian society presented from the perspective of descriptive ethics. Currently she works at the Institute of Archaeology and Ethnology of the Polish Academy of Sciences in Warsaw. E-mail: 3margad@gmail.com 